\title{
FAKTOR YANG MEMPENGARUHI AUDITOR SWITCHING TERHADAP PROPERTY DAN REAL ESTATE PERIODE 2017-2019
}

\author{
Tengku Suripah Rani Mutiah ${ }^{1}$ \\ Riana Rachmawati Dewi ${ }^{2}$ \\ Rosa Nikmatul Fajri ${ }^{3}$ \\ ${ }^{1}$ Fakultas Ekonomi, Universitas Islam Batik Surakarta \\ Email : tengkusuripah@gmail.com \\ ${ }^{2}$ Fakultas Ekonomi, Universitas Islam Batik Surakarta \\ Email : rianardewi1@ gmail.com \\ ${ }^{3}$ Fakultas Ekonomi, Universitas Islam Batik Surakarta \\ Email : rosanikmatulfajri@mail.ugm.ac.id
}

\begin{abstract}
This study aims to determine the effect of financial distress, KAP size, management turnover, audit opinion, and firm size on auditor switching. The population in this study is the Property and Real Estate companies on the Indonesia Stock Exchange (BEI) 2017-2019. The sample was selected by purposive sampling method and got 106 companies from several criteria. The data source is secondary data from the website (www.idx.co.id). This study uses logistic regression analysis with the help of SPSS version 21 program. The results show that firm size has an effect on auditor switching, while financial distress, KAP size, management turnover, and audit opinion have no effect on auditor switching.
\end{abstract}

Keywords: auditor switching, financial distress, KAP size, management turnover, audit opinion

\section{PENDAHULUAN}

Laporan keuangan adalah suatu laporan yang menggambarkan hasil dari proses akuntansi yang digunakan sebagai alat komunikasi bagi kelompok yang bersangkutan dengan data keuangan atau aktivitas perusahaan (Sundjaja \& Barlian, 2001). Dalam Standar Akuntansi Keuangan (SAK) menyebutkan bahwa laporan keuangan bertujuan untuk menyajikan informasi berhubungan dengan posisi keuangan, kinerja dan perubahan posisi keuangan suatu entitas yang berguna untuk investor dalam mengambil keputusan. Oleh karena itu, informasi yang tersedia pada laporan keuangan harus relevan dan reliabel dalam menjelaskan situasi perusahaan. Demi menjaga kewajaran laporan keuangan perusahaan maka diperlukan pemeriksaan yang dilakukan oleh auditor independen. Kriteria utama yang dibutuhkan oleh auditor adalah independensi.

KMK No. 423/KMK.06/2002 mengenai penetapan praktik akuntan publik, diharapkan mampu menjaga independensi auditor sehingga mutu audit menjadi lebih terjamin. Belakangan ini ada beberapa kasus yang terjadi mengenai hasil kualitas audit yang dihasilkan oleh akuntan publik. Salah satunya yaitu kasus yang menyangkut PT Garuda Indonesia Tbk dan AP Kasner Sirumapea yang terbukti membuat pelanggaran pada laporan keuangan PT Garuda Indonesia tahun buku 2018. Akibat dari skandal ini Menteri Keuangan Sri Mulyani memberikan hukuman bagi Akuntan Publik (AP) Kasner Sirumapea dalam bentuk pembekuan izin 12 bulan lamanya (KMK No./KM.1/2019 tanggal 27-062019) sebab melakukan kesalahan berat yang berpeluang berdampak signifikan pada opini Laporan Auditor Independen juga beserta peringatan tertulis dengan disertai kewajiban untuk memperbaiki Sistem Pengendalian Mutu KAP dan diadakan peninjauan oleh BDO International Limited (Surat No.S210/MK.1PPPK/2019 tanggal 26 Juni 2019) (Hermansyah \& Fadil, 2019).

Di samping itu, terdapat pula PT Inovisi Infracom Tbk, dimana banyak ditemukan adanya kesalahan dalam laporan keuangan kuartal III tahun 2014. Perusahaan ini memilih Kreston Internasional (Hendrawinata, Eddy Siddarta, Tanzil dan rekan) untuk mengaudit laporan keuangannya, yang sebelumnya memilih oleh KAP Jamaludin, Ardi, Sukimto dan rekan untuk mengaudit laporan keuangannya. Pergantian ini dilakukan dengan tujuan menjaga laporan keuangan yang berkualitas sesuai dengan standar akuntansi yang berlaku umum. Akibat dari kesahalan tersebut, PT Inovisi Infracom mendapat hukuman penghapusan (delisting) saham pada Bursa Efek Indonesia yang berlaku efektif mulai 23 Oktober 2017 (Sugianto, 2017).

Kepercayaan investor harus dikembalikan akibat adanya skandal PT Garuda Indonesia Tbk dan PT Inovisi Infracom Tbk, salah satu caranya yaitu melalui The Sarbanes Oxley Act (SOX) yang 
diciptakan oleh Amerika Serikat pada tahun 2002. SOX digunakan untuk memperbaiki struktur kepengawasan pada KAP melalui penerapan rotasi KAP maupun auditornya (auditor switching).

Auditor switching adalah pergantian auditor maupun KAP untuk melakukan tugas audit pada sebuah perusahaan. Pihak manajemen beranggapan bahwa mengganti auditor maupun KAP, maka perusahaan memiliki peluang mendapatkan auditor yang mempunyai pendirian sesuai dan sejalan dengan perusahaan. Terdapat dua jenis pergantian terjadinya rotasi KAP ataupun auditornya (auditor switching), yaitu secara mandatory dan voluntary. Pergantian secara mandatory adalah perubahan yang dilakukan berdasarkan peraturan wajib pemerintah yang berlaku. Sementara pergantian secara voluntary adalah perubahan yang dilakukan bukan berdasarkan peraturan wajib pemerintah, tetapi dilakukan karena sukarela berdasarkan kemauan manajemen. Peraturan yang membahas mengenai pergantian auditor di Indonesia terdapat dalam Peraturan Menteri Keuangan (PMK) No. 17/PMK.01/2008 tentang "Jasa Akuntan Publik" pada pasal 3 ayat (1) dijelaskan bahwa sebuah KAP hanya boleh mengaudit suatu perusahaan paling lama 6 tahun buku berturut-turut dan Akuntan Publik (AP) dalam KAP tersebut diperbolehkan mengaudit paling lama 3 tahun buku berturut-turut. Namun pada tahun 2015, diterbitkan peraturan yang membahas tentang pergantian auditor di Indonesia tercantum dalam Peraturan pemerintah PP No.20/2015 pasal 11 ayat (1) mengenai Praktik Akuntan Publik bahwa pembatasan berlaku untuk AP selama lima tahun buku berturut-turut, sehingga jelas bahwa tidak ada lagi batasan untuk KAP dalam mengaudit.

Kesulitan keuangan merupakan salah satu faktor mengakibatkan terjadinya auditor switching. Kusuma \& Farida (2019) menyebutkan bahwa masalah keuangan seringkali berakibat dilakukannya auditor switching dalam perusahaan dibandingkan dengan perusahaan yang tidak bermasalah dalam bidang keuangan, hal ini disebabkan sebuah perusahaan dalam kondisi kesulitan keuangan otomatis mengalami kesulitan memenuhi kewajiban perusahaan dan membayar biaya auditornya. Alasan inilah yang membuat perusahaan merasakan tidak aman dan cenderung untuk berganti auditor. Berbeda dengan Andini et al. (2020) menyebutkan bahwa perusahaan yang mengalami kesulitan keuangan tidak memengaruhi auditor switching.

Ukuran KAP juga merupakan salah satu faktor mengakibatkan terjadinya auditor switching. Penanam modal cenderung meyakini integritas hasil audit laporan keuangan oleh KAP yang bereputasi (Sinarwati, 2010). Penelitian Safriliana \& Muawanah (2019) menyebutkan bahwa ukuran KAP memengaruhi auditor switching, dimana KAP bigfour dianggap mempunyai independensi lebih tinggi serta lebih mampu menahan tuntutan dari manajemen. Berbeda dengan Aroh et al. (2017) memberikan hasil bahwa ukuran KAP tidak memengaruhi auditor switching.

Pergantian Manajemen juga merupakan salah satu faktor mengakibatkan terjadinya auditor switching. Apabila manajemen terpilih yang baru berpandangan auditor terdahulu tidak sesuai dengan kebijakannya dan memiliki pandangan tersendiri perihal pemilihan auditor, hal ini dimungkinkan mengarah terhadap auditor switching. Penelitian oleh Kusuma \& Farida (2019) menyebutkan bahwa pergantian manajemen dapat memengaruhi auditor switching, hal ini dimungkinkan dengan adanya pergantian manajemen bertujuan untuk menjaga eksistensi perusahaan dalam lingkungan bisnis yang kompetitif guna meningkatkan kinerja perusahaan. Berbeda dengan Andreas \& Savitri, (2019) memberikan hasil bahwa pergantian manajemen tidak memengaruhi auditor switching.

Opini Audit juga merupakan salah satu faktor mengakibatkan terjadinya auditor switching. Opini audit adalah di mana auditor memberikan pendapat mengenai hasil penyajian laporan keuangan yang wajar pada perusahaan tempat auditor melaksanakan audit (Mulyadi, 2014). Penelitian oleh Rahmi et al. (2019) berhasil membuktikan opini audit memengaruhi auditor switching, hasil yang diperoleh menunjukkan bahwa mutu opini yang dihasilkan oleh auditor dapat menjadi penentu perusahaan dalam melakukan auditor switching. Ketika opini yang diberikan auditor selain opini wajar tanpa pengecualian, maka perusahaan lebih memilih untuk mengganti KAP yang dianggap dapat memberikan opini sesuai harapan perusahaan. Hal tersebut akan terus dilakukan oleh perusahaan, hingga akhirnya perusahaan menemukan auditor yang dapat memberikan opini sesuai dengan harapan perusahaan. Berbeda dengan Safriliana \& Muawanah (2019) menemukan bahwa opini audit tidak memengaruhi auditor switching.

Ukuran perusahaan juga merupakan salah satu faktor mengakibatkan terjadinya auditor switching. Besar kecilnya perusahaan dapat diukur berdasarkan kondisi keuangan perusahaan (Pradhana, 2015). Penelitian oleh Pratiwi \& RM (2019) menyebutkan bahwa ukuran perusahaan memengaruhi auditor switching, hal ini bisa menguatkan teori agensi bahwa ketika ukuran perusahaan 
mengalami peningkatan akan bepengaruh juga terhadap kompleksitas perusahaan sehingga terjadi peningkatan kesulitan pemegang saham sebagai principal dalam mengawasi aktivitas manajemen sebagai agent, serta manajemen cenderung mengadakan perubahan auditor dan menunjuk auditor lebih besar yang dipandang mempunyai mutu dan independensi yang tinggi karena dipandang lebih ahli memenuhi kebutuhan principal dan agent. Berbeda dengan Rahmi et al. (2019) memberikan hasil bahwa tidak ada pengaruh antara ukuran perusahaan dengan auditor switching.

Berdasarkan penjelasan di atas, maka diambil rumusan masalah sebagai berikut : "Apakah kesulitan keuangan, ukuran KAP, pergantian manajemen, opini audit, dan ukuran perusahaan berpengaruh terhadap auditor switching?". Tujuan penelitian adalah menguji dan menganalisis pengaruh kesulitan keuangan, ukuran KAP, pergantian manajemen, opini audit, dan ukuran perusahaan berpengaruh terhadap auditor switching.

\section{KAJIAN PUSTAKA DAN PENGEMBANGAN HIPOTESIS}

\section{Teori Agensi (agency theory)}

Teori agensi adalah teori tentang hubungan perjanjian antar pihak di perusahaan (Ramadona, 2016). Teori yang menggambarkan bahwa keagenan timbul saat satu orang atau lebih (principal) meminta orang lain (agent) melakukan pekerjaan dan pelimpahan wewenang pembuatan keputusan pada agen (Ichsan, 2013). Dari beberapa pengertian tersebut disimpulkan bahwa teori agensi adalah teori yang menggambarkan hubungan antara pemegang saham (principal) dan manajemen (agent). Manajemen merupakan pihak yang dikontrak oleh principal untuk bekerja demi kepentingan principal. Konflik kepentingan antara pihak agent dan principal perusahaan ini dapat menimbulkan adanya pergantian manajemen yang dilakukan berdasarkan keputusan RUPS. Pergantian manajemen bertujuan mengimplementasikan kebijakan akuntansi baru serta adanya keputusan pergantian KAP (auditor switching).

\section{Auditor Switching}

Auditor Switching yaitu perubahan auditor atau kantor akuntan publik (KAP) yang terjadi pada suatu entitas atau perusahaan klien. Auditor Switching diadakan guna melindungi sikap independensi auditor yang ditakutkan akibat lamanya hubungan diantara auditor dan klien dapat menyebabkan relasi kerja yang kurang baik (Faradina \& Efrizal, 2019). Dapat disimpulkan bahwa auditor switching adalah pergantian auditor maupun KAP yang melakukan penugasan audit pada suatu entitas atau perusahaan guna menjaga independensi auditor. Pemberian jasa audit umum atas laporan keuangan dari suatu entitas dapat dilakukan oleh KAP paling lama untuk 5 tahun buku berturut-turut oleh seorang akuntan publik paling lama untuk 3 tahun buku berturut-turut.

\section{Kesulitan Keuangan (Financial Distress)}

Kesulitan keuangan ialah situasi ketika tidak terpenuhinya kewajiban lancar akibat tidak tercukupinya cash flow operasi perusahaan (Ross et al., 2013). Kesulitan keuangan merupakan kondisi di mana suatu perusahaan tidak mampu memenuhi kewajibannya, kondisi di mana total biaya tidak dapat dipenuhi dengan pendapatan perusahaan sehingga terjadi kerugian. Menurut kreditur, ini merupakan awal dari kegagalan debitur (Hery, 2016). Kesulitan keuangan sering terjadi pada perusahaan yang tidak sanggup lagi atau gagal dalam hal memenuhi kewajiban debitur yang diakibatkan ketidakcukupan atau kekurangan dana untuk melanjutkan lagi operasional usahanya.

\section{Ukuran KAP (KAP Size $)$}

Ukuran KAP adalah standar dalam penentuan besar kecilnya suatu kantor akuntan publik (Juliantari \& Rasmini, 2013). Suatu perusahaan akan berganti auditor dari kecil ke besar guna menumbuhkembangkan reputasi dan mutu laporan keuangannya, oleh karena itu ukuran KAP adalah gambaran besar kecilnya Kantor Akuntan Publik, semakin besar ukuran KAP maka semakin tinggi kualitas audit yang dihasilkan (Arsih \& Anisykurlillah, 2015). Dari beberapa pengertian tersebut disimpulkan bahwa ukuran KAP (KAP Size) adalah besar kecilnya Kantor Akuntan Publik yang digunakan suatu perusahaan untuk memerika laporan keuangan perusahaan. Apabila dihubungkan keberadaannya KAP yang ada di Indonesia, maka ukuran KAP terbesar yakni KAP yang berafiliasi dengan KAP asing yang tergolong Big four. 


\section{Pergantian Manajemen (Management Turnover)}

Pergantian manajemen bisa diartikan bergantinya direksi suatu perusahaan akibat adanya putusan rapat umum pemegang saham (RUPS) atau dikarenakan direksi yang berkendak untuk berhenti. Penyebab pergantian manajemen bisa juga dimungkinkan oleh adanya pergantian kebijakan di bidang akuntansi, keuangan, dan pemilihan KAP (Lindrianasari, 2010). Jika pada suatu perusahaan terjadi pergantian manajemen, entah secara langsung maupun tidak langsung akan memaksa auditor agar sesuai dalam kebijakan akuntansi dan sistem pelaporanya (Pratini \& Astika, 2013). Oleh karena itu, disimpulkan bahwa dengan adanya pergantian manajemen memungkinkan klien untuk memilih auditor baru yang lebih berkualitas dan sesuai dengan kebijakan akuntansi perusahaan.

\section{Opini Audit (Audit Opinion)}

Opini audit adalah di mana auditor memberikan pendapat mengenai hasil penyajian laporan keuangan yang wajar pada perusahaan tempat auditor melaksanakan audit (Mulyadi, 2014). Opini audit yaitu keputusan akhir penilaian atas kewajaran laporan entitas dari auditor (Aurora, 2013). Oleh karena itu, disimpulkan bahwa opini audit adalah hasil dari proses audit yang dilakukan oleh auditor independen guna menyampaikan hasil evaluasinya mengenai kewajaran laporan keuangan yang diperiksa, serta sebagai bentuk pertanggungjawaban kepada pihak ketiga.

\section{Ukuran Perusahaan (Firm Size)}

Ukuran perusahaan merupakan besar kecilnya perusahaan dapat diukur berdasarkan kondisi keuangan perusahaan (Pradhana, 2015). Ukuran perusahaan adalah besar kecilnya perusahaan yang dapat diketahui dari besarnya nilai ekuitas, nilai penjualan atau nilai aktiva (Riyanto, 2013). Oleh karena itu, disimpulkan bahwa ukuran perusahaan adalah suatu skala yang dapat dihitung dengan tingkat total aset dan penjualan yang dapat menunjukkan kondisi perusahaan di mana perusahaan lebih besar akan mempunyai kelebihan sumber dana untuk membiayai invetasinya dalam memperoleh laba.

\section{Penelitian Terdahulu}

Penelitian Abidin et al. (2016) memberikan hasil bahwa Non Eksekutif Director Board (NEDBod), Non Audit Service (NAS), Management Change, Firm Size, Opinion Audit, dan KAP Size memengaruhi auditor switching. Penelitian Agiastuti \& Suputra (2016) memberikan hasil bahwa variable financial distress, going concern opinion, management changes, dan reputasi KAP dapat memengaruhi auditor switching. Penelitian Aroh et al., (2017) memberikan hasil bahwa tipe industri memengaruhi auditor switching, sedangkan financial distress, audit firm size dan ownership concentration tidak memengaruhi auditor switching. Penelitian Winata \& Anisykurlillah, (2018) memberikan hasil bahwa KAP Size, management turnover, dan size of company memengaruhi auditor switching, sedangkan financial distress dan audit opinion tidak memengaruhi auditor switching. Penelitian Andini et al., (2020) memberikan hasil bahwa opini audit, kepemilikan publik, kesulitan keuangan, dan fee audit tidak memengaruhi auditor switching.

\section{Kerangka Konseptual Penelitian}

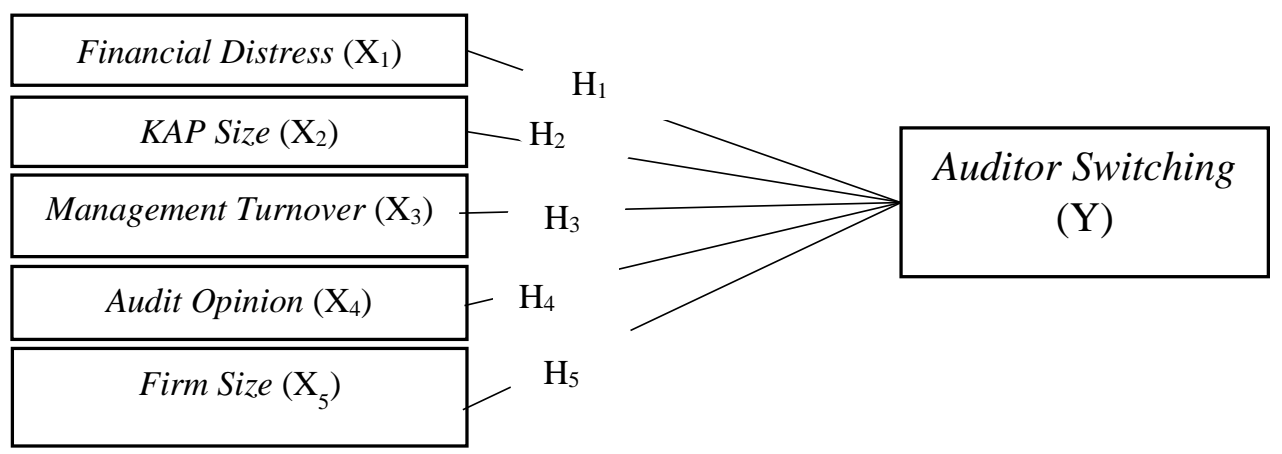

Gambar 1. Kerangka Konseptual Penelitian 


\section{Pengaruh Kesulitan Keuangan terhadap Auditor Switching}

Kesulitan keuangan ialah situasi ketika tidak terpenuhinya kewajiban lancar akibat tidak tercukupinya cash flow operasi perusahaan. Penelitian Kusuma \& Farida, (2019) mengatakan bahwa kesulitan keuangan memengaruhi auditor switching. Di sisi lain Andini et al., (2020) menemukan bahwa kesulitan keuangan tidak memengaruhi auditor switching.

$\mathrm{H} 1$ : kesulitan keuangan berpengaruh terhadap auditor switching.

\section{Pengaruh Ukuran KAP terhadap Auditor Switching}

Ukuran KAP adalah standar dalam penentuan besar kecilnya suatu kantor akuntan publik (Juliantari \& Rasmini, 2013). Perusahaan akan mencari KAP Big Four sebab memandang mutu auditnya lebih baik, mutu laporan keuangan perusahaan akan meningkatkan di mata investor sehingga reputasi perusahaan menjadi baik (Pradhana, 2015). Penelitian Safriliana \& Muawanah (2019) mengatakan ukuran KAP memengaruhi auditor switching. Di sisi lain Aroh et al., (2017) menemukan ukuran KAP tidak memengaruhi auditor switching.

$\mathrm{H} 2$ : ukuran KAP berpengaruh terhadap auditor switching.

\section{Pengaruh Pergantian Manajemen terhadap Auditor Switching}

Pergantian Manajemen bisa juga dimungkinkan oleh adanya pergantian kebijakan di bidang akuntansi, keuangan, dan pemilihan KAP. Pihak manajemen membutuhkan auditor berkualitas tinggi yang sanggup menyelesaikan ketentuan dari perusahaan berupa tuntutan pertumbuhan perusahaan yang cepat, dan perusahaan akan mengganti KAP yang sesuai dengan kebijakan dan pelaporan akuntansinya (Pradhana, 2015). Penelitian Winata \& Anisykurlillah (2018) mengatakan bahwa pergantian manajemen memengaruhi auditor switching. Di sisi lain penelitian Andreas \& Savitri (2019) menemukan pergantian manajemen tidak memengaruhi auditor switching.

H3 : pergantian manajemen berpengaruh terhadap auditor switching.

\section{Pengaruh Opini Audit terhadap Auditor Switching}

Opini Audit adalah di mana auditor memberikan pernyataan atau pendapatnya terhadap laporan keuangan perusahaan. Opini auditor menentukan baik buruknya kondisi keuangan perusahaan. Apabila opini auditor memberikan opini selain wajar tanpa pengecualian besar kemungkinan perusahaan akan mencari auditor yang baru, dikarenakan dengan opini tersebut akan merusak reputasi perusahaan di mata investor. Penelitian Susanto (2018) mengatakan bahwa opini audit memengaruhi auditor switching. Di sisi lain penelitian Andini et al., (2020) menemukan opini audit tidak memengaruhi auditor switching.

H4 : opini audit berpengaruh terhadap auditor switching.

\section{Pengaruh Ukuran Perusahaan terhadap Auditor Switching}

Ukuran Perusahaan adalah suatu perusahaan dapat dikategorikan berdasarkan total aset. Semakin besar total aset suatu perusahaan, maka membuktikan semakin besar pula ukuran perusahaan tersebut, begitupun sebaliknya. Penelitian Pratiwi \& RM (2019) mengatakan ukuran perusahaan memengaruhi auditor switching. Di sisi lain Rahmi et al., (2019) menemukan ukuran perusahaan tidak memengaruhi auditor switching.

H5 : ukuran perusahaan berpengaruh terhadap auditor switching.

\section{METODE PENELITIAN}

Jenis penelitian yang digunakan adalah pendekatan kuantitatif. Pendekatan kuantitatif merupakan strategi untuk mengamati populasi atau sampel tertentu dengan menganalisis data bersifat kuantitatif dengan tujuan untuk menguji hipotesis yang telah ditetapkan (Sugiyono, 2013). Sumber data yang penelitian adalah data sekunder. Data sekunder ialah data yang didapatkan secara tidak langsung dengan media perantara, baik yang diterbitkan dan tidak diterbitkan. Data yang dibutuhkan terdapat dalam laporan keuangan (annual report) yang diaudit dan dipublikasikan di BEI selama periode 20172019 perusahaan property dan real estate dari BEI (www.idx.co.id). Populasi penelitian seluruh perusahaan property dan real estate yang tercatat di Bursa Efek Indonesia periode 2017-2019. Periode penelitian dalam penelitian yaitu tahun 2017-2019 dengan alasan karena merupakan data terbaru. Sampel penelitian menggunakan teknik purposive sampling, di mana hasil akhir menjadi 106 sampel. Data dianalisis menggunakan regresi logistik. 


\section{Variabel Penelitian dan Pengukuran}

Auditor Switching diukur menggunakan variable dummy, nilai 1 menunjukkan adanya auditor switching pada perusahaan, dan nilai 0 menunjukkan tidak ada auditor switching pada perusahaan (Efendy \& Rahayu, 2015). Kesulitan keuangan dihitung menggunakan DER. Dimana rasio ini dihitung dengan cara membagi seluruh liabilitas, termasuk liabilitas lancar dengan seluruh equity (Kasmir, 2016). Menurut Hilmi \& Ali (2008) metode ukuran KAP diukur menggunakan variabel dummy, nilai 1 menunjukkan perusahaan diaudit oleh KAP yang berafiliasi dengan big four dan nilai 0 menunjukkan perusahaan diaudit menggunakan KAP yang berafiliasi dengan non big four. Pergantian Manajemen diukur menggunakan variabel dummy, nilai 1 menunjukkan terjadi pergantian direktur utama dalam perusahaan, dan nilai 0 menunjukkan tidak terjadi pergantian direktur utama dalam perusahaan (Aprilia, 2013). Opini audit diukur menggunakan variable dummy, nilai 1 menunjukkan perusahaan klien menerima opini wajar tanpa pengecualian atas laporan keuangan yang disajikan, dan nilai 0 menunjukkan perusahaan yang memperoleh opini selain wajar tanpa pengecualian (Damayanti \& Sudarma, 2012). Ukuran perusahaan bisa dihitung dengan jumlah total aset perusahaan sampel kemudian dikonversikan ke dalam bentuk logaritma natural (ln) (Widiastari \& Yasa, 2018).

\section{Metode Analisis Data}

Penelitian ini menggunakan analisis regresi logistik. Alasan menggunakan analisis regresi logistik sebab variabel independen bersifat dikotomi (melaksanakan auditor switching dan tidak melaksanakan auditor switching) dan dalam analisis regresi logistik tidak diperlukan asumsi normalitas dan juga heteroskedastisitas. Persamaan penelitian dapat dirumuskan sebagai berikut :

Keterangan :

$$
\operatorname{Ln} \frac{\mathrm{AS}}{1-\mathrm{AS}}=\alpha+\beta_{1} \mathrm{FD}+\beta_{2} \mathrm{KAP}+\beta_{3} \mathrm{MT}+\beta_{4} \mathrm{AO}+\beta_{5} \mathrm{SIZE}+\varepsilon
$$

$$
\begin{aligned}
& \operatorname{Ln} \frac{A S}{1-A S} \quad=\text { Auditor Switching } \\
& \alpha=\text { Konstanta } \\
& \beta_{1}-\beta_{5}=\text { Koefisien Regresi } \\
& \text { FD= Financial Distress } \\
& \text { KAP } \quad=\text { KAP Size } \\
& \text { MT }=\text { Management Turnover } \\
& \mathrm{AO}=\text { Audit Opinion } \\
& \text { SIZE } \quad=\text { Firm Size } \\
& \varepsilon=\text { Error }
\end{aligned}
$$

\section{HASIL DAN PEMBAHASAN}

Uji Statistik Deskriptif

Tabel 1

Statistik Deskriptif

\begin{tabular}{llrrrr}
\hline & N & \multicolumn{1}{c}{ Minimum } & Maximum & \multicolumn{1}{c}{ Mean } & \multicolumn{1}{c}{ Std. Deviation } \\
\hline AS & 106 &, 000 & 1,000 &, 170 &, 377 \\
FD & 106 &, 001 & 1,606 &, 521 &, 427 \\
KAP & 106 &, 000 & 1,000 &, 235 &, 426 \\
MT & 106 &, 000 & 1,000 &, 104 &, 306 \\
AO & 106 &, 000 & 1,000 &, 991 &, 097 \\
SIZE & 106 & 23,750 & 31,670 & 28,803 & 1,929 \\
Valid (N) & 106 & & & & \\
(listwise) & & & & & \\
\hline
\end{tabular}

Sumber : Diolah dengan SPSS 21

Berdasarkan tabel 1 hasil analisis deskripsi menunjukkan hasil analisis deskriptif variabel auditor switching diperoleh nilai min 0 , nilai maks 1 , nilai mean 0,170 dan standar deviasi 0,377 . Hasil penelitian menunjukan ukuran penyebaran dari variabel auditor switching adalah 37,7\% dari 106 perusahaan yang diteliti. Variabel kesulitan keuangan menunjukkan nilai min 0,001 nilai maks 1,606 nilai mean 0,521 dan standar deviasi 0,427 . Hasil ini menunjukkan ukuran penyebaran dari variabel 
kesulitan keuangan adalah 42,7\% dari 106 perusahaan yang diteliti. Variabel ukuran KAP diperoleh nilai min 0 , nilai maks 1 , nilai mean 0,235 dan standar deviasi 0,426 . Hasil penelitian ini menunjukan ukuran penyebaran dari variabel ukuran KAP adalah 42,6\% dari 106 perusahaan yang diteliti. Variabel pergantian manajemen menunjukkan nilai min 0 , nilai maks 1 , nilai mean 0,104 dan standar deviasi 0,306. Hasil penelitian menunjukan ukuran penyebaran variabel pergantian manajemen adalah 30,6\% dari 106 perusahaan yang diteliti. Variabel opini audit menunjukkan nilai min 0 , nilai maks 1 , nilai mean sebesar 0,991 dan standar deviasi 0,097. Hasil penelitian menunjukan ukuran penyebaran variabel opini audit adalah 9,7\% dari 106 perusahaan yang diteliti. Variabel ukuran perusahaan menunjukkan nilai min 23,750 , nilai maks 31,670 , nilai mean sebesar 28,803 dan standar deviasi 1,929 . Hasil penelitian menunjukan ukuran penyebaran dari variabel ukuran perusahaan adalah 192,9\% dari 106 perusahaan yang diteliti.

\section{Uji Asumsi Klasik}

\section{a) Uji Multikolinieritas}

Tabel 2

Hasil Uji Multikolinieritas

\begin{tabular}{cccl}
\hline Variabel & Tolerance & VIF & Ket \\
\hline FD &, 801 & 1,248 & Tidak Terjadi Multikolinieritas \\
KAP &, 906 & 1,104 & Tidak Terjadi Multikolinieritas \\
MT &, 959 & 1,043 & Tidak Terjadi Multikolinieritas \\
AO &, 983 & 1,018 & Tidak Terjadi Multikolinieritas \\
SIZE &, 733 & 1,365 & Tidak Terjadi Multikolinieritas \\
\hline
\end{tabular}

Sumber : Diolah dengan SPSS 21

Berdasarkan tabel 2 hasil uji multikolinieritas menunjukkan hasil semua variabel independen mempunyai nilai Tolerance $\geq 0,10$ dan nilai VIF $\leq 10$. Sehingga, dapat ditarik kesimpulan bahwa seluruh variabel inedependen penelitian ini tidak terjadi multikolinieritas.

\section{Uji Regresi Logistic}

Tabel 3

Hasil Uji Regresi Logistik

\begin{tabular}{lrrrrrr}
\hline & \multicolumn{1}{c}{ B } & \multicolumn{1}{c}{ S.E. } & Wald & df & \multicolumn{1}{c}{ Sig. } & \multicolumn{1}{c}{$\operatorname{Exp~(B)~}$} \\
\hline FD & 0,637 & 0,687 & 0,859 & 1 & 0,354 & 1,890 \\
KAP & 0,343 & 0,680 & 0,225 & 1 & 0,614 & 1,409 \\
MT & $-0,134$ & 0,869 & 0,24 & 1 & 0,877 & 0,874 \\
AO & 18,904 & 40192,992 & 0,000 & 1 & 1,000 & 162152164,864 \\
SIZE & 0,334 & 0,156 & 4,622 & 1 & 0,32 & 0,716 \\
Constant & $-11,349$ & 40192,992 &, 000 & 1 & 1,000 & 0,000 \\
\hline
\end{tabular}

Sumber : Diolah dengan SPSS 21

Maka dapat diinterpretasikan koefisien konstanta adalah sebesar -11,349 yang memiliki nilai negative, hal ini menunjukkan bahwa penyebab auditor switching bukan hanya variabel kesulitan keuangan, ukuran KAP, pergantian manajemen, opini audit, dan ukuran perusahaan tetapi juga variabel lain yang memengaruhi di luar variabel penelitian. Nilai koefisien regresi variabel kesulitan keuangan sebesar 0,637. Hal ini menunjukkan bahwa apabila jenjang kesulitan keuangan semakin besar, maka dilakukan auditor switching pada perusahaan. Sebaliknya, jika kesulitan keuangan semakin kecil, maka tidak dilakukan auditor switching pada perusahaan. Nilai koefisien regresi variabel ukuran KAP sebesar 0,343 . Hal ini menunjukkan bahwa apabila tingkat ukuran KAP semakin besar maka, perusahaan akan melakukan auditor switching. Sebaliknya, apabila ukuran KAP semakin kecil, maka perusahaan tidak akan melakukan auditor switching. Nilai koefisien regresi variabel pergantian manajemen sebesar 0,134 . Hal ini menunjukkan bahwa jika kemungkinan pergantian manajemen semakin kecil maka perusahaan tidak melakukan auditor switching. Sebaliknya, apabila kemungkinan pergantian manajemen semakin besar, maka perusahaan melakukan auditor switching. Nilai koefisien regresi variabel opini audit sebesar 18,904. Hal ini menunjukkan bahwa jika tingkat opini audit semakin besar maka, dilakukan auditor switching pada perusahaan. Sebaliknya, jika tingkat opini audit semakin kecil maka, tidak dilakukan auditor switching pada perusahaan. Nilai koefisien regresi variabel ukuran 
perusahaan sebesar 0,334. Hal ini menunjukkan apabila tingkat ukuran perusahaan semakin besar maka, dilakukan auditor switching pada perusahaan. Sebaliknya, apabila tingkat ukuran perusahaan semakin kecil maka, tidak dilakukan auditor switching pada perusahaan.

\section{a) Menilai Keseluruhan Model (Overall Model Fit)}

\begin{tabular}{lr}
\multicolumn{2}{c}{ Tabel 4 } \\
-2 log likelihood \\
\hline -2 log likelihood awal (Block 0) & 93,789 \\
-2 log likelihood akhir (Block 1) & 91,521 \\
Penurunan -2 log likelihood & 2,268 \\
\hline Sumber : Diolah dengan SPSS 21
\end{tabular}

Berdasarkan tabel 4 hasil uji kelayakan melalui mengamati nilai pada awal -2 log likelihood block 0, sebesar 93,789 dan angka -2 log likelihood block 1, sebesar 91,521. Hal ini membuktikan adanya penurunan nilai -2 log likelihood sebesar 2,268. Penurunan nilai tersebut dapat dikatakan juga bahwa model yang dihipotesiskan fit dengan data.

b) Menguji Kelayakan Model Regresi (Chi Square Hosmer and Lemeshow)

Tabel 5

Hasil Uji Hosmer and Lemeshow Test

\begin{tabular}{ccccc}
\hline Step & Chi-square & Sig. & Standar & Keterangan \\
\hline 1 & 8,770 & 0,362 & $>0,05$ & $\mathrm{H}_{0}$ diterima \\
\hline
\end{tabular}

Sumber : Diolah dengan SPSS 21

Berdasarkan tabel 5 hasil uji kelayakan model regresi (Chi Square Hosmer And Lemeshow), diperoleh Chi-square sebesar 8,770 dengan nilai signifikansi sebesar 0,362. Dari hasil tersebut terlihat bahwa nilai signifikansi lebih besar dari 0,05 sehingga hipotesis nol diterima, yang berarti tidak ada perbedaan antara klasifikasi yang diprediksi dengan klasifikasi yang diamati. Sehingga dapat disimpulkan bahwa pada model regresi yang digunakan telah memenuhi kecukupan data ( $f i t)$.

\section{c) Hasil Uji Koefisien Determinasi}

\section{Tabel 6}

Nilai Nagelkerke R Square

\begin{tabular}{lccc}
\hline Step & -2 Log likelihood & Cox \& Snell R Square & Nagelkerke R Square \\
\hline 1 & 91,388 & 0,048 & 0,080 \\
\hline
\end{tabular}

Sumber : Diolah dengan SPSS 21

Berdasarkan tabel 6 hasil uji koefisien determinasi, uji model -2 Log Likelihood menghasilkan 91,388, Nagelkerke $R$ Square adalah 0,080 (8\%) dan nilai Cox \& Snell $R$ Square $0,048(4,8 \%)$. Diartikan variabel independen kesulitan keuangan, ukuran KAP, pergantian manajemen, opini audit, dan ukuran perusahaan dapat menunjukkan variasi dari variabel dependen auditor switching sebesar 8\%, sementara itu sisanya ditunjukkan oleh faktor lain di luar penelitian ini.

d) Hasil Uji Matriks Klasifikasi

Tabel 7

Classification Table ${ }^{\mathrm{a}, \mathrm{b}}$

\begin{tabular}{ccccc}
\hline & & $\begin{array}{c}\text { Tidak } \\
\text { Auditor } \\
\text { Switching }\end{array}$ & $\begin{array}{c}\text { Auditor } \\
\text { Switching }\end{array}$ & $\begin{array}{c}\text { Percentage } \\
\text { Correct }\end{array}$ \\
\hline \multirow{2}{*}{$\begin{array}{c}\text { Step } \\
0\end{array}$} & $\begin{array}{c}\text { Tidak Auditor } \\
\text { Switching }\end{array}$ & 88 & 0 & 100,0 \\
\cline { 2 - 5 } & Auditor Switching & 18 & 0 &, 0 \\
\cline { 2 - 5 } & Overall Percentage & & & 83,0 \\
\hline
\end{tabular}

Sumber : Diolah dengan SPSS 21 
Berdasarkan tabel 7 hasil uji matriks klasifikasi, menunjukkan hasil kekuatan yang digunakan untuk menduga terjadinya auditor switching pada perusahaan sebesar $0,0 \%$. Hal ini menjelaskan bahwa dengan model regresi yang digunakan, terdapat 0 sampel $(0,0 \%)$ yang diduga akan melakukan auditor switching dari total 18 sampel yang melakukan auditor switching. Kekuatan dugaan model perusahaan yang tidak melakukan auditor switching sebesar 100\%. Hal ini menjelaskan dengan model regresi yang digunakan sebanyak 88 sampel (100\%) yang diduga tidak akan melakukan auditor switching dari total 88 sampel yang tidak melakukan auditor switching.

e) Pengujian Hipotesis

Tabel 8

Uji Hipotesis

\begin{tabular}{lccc}
\hline & Sig. & Standar & Keterangan \\
\hline Financial Distress &, 354 & $>0,05$ & Ditolak \\
KAP Size &, 614 & $>0,05$ & Ditolak \\
Managament Turnover &, 877 & $>0,05$ & Ditolak \\
Audit Opinion & 1,000 & $>0,05$ & Ditolak \\
Firm Size &, 032 & $<0,05$ & Diterima \\
\hline
\end{tabular}

Sumber : Diolah dengan SPSS 21

Berdasarkan tabel 8 hasil uji hipotesis dapat disimpulkan :

a. Kesulitan keuangan menunjukkan nilai signifikansi sebesar 0,354 yang lebih dari 0,05, maka kesulitan keuangan tidak berpengaruh terhadap auditor switching.

b. Ukuran KAP menunjukkan nilai signifikansi sebesar 0,614 yang lebih dari 0,05, maka Ukuran KAP tidak berpengaruh terhadap auditor switching.

c. Pergantian manajemen menunjukkan nilai signifikansi sebesar 0,877 yang lebih dari 0,05, maka pergantian manajemen tidak berpengaruh terhadap auditor switching.

d. Opini audit menunjukkan nilai signifikansi sebesar 1,000 yang lebih dari 0,05, maka opini audit tidak berpengaruh terhadap auditor switching.

e. Ukuran perusahaan menunjukkan nilai signifikansi sebesar 0,032 yang kurang dari 0,05, maka ukuran perusahaan berpengaruh terhadap auditor switching.

\section{PEMBAHASAN}

\section{Pengaruh Kesulitan Keuangan terhadap Auditor Switching}

Hasil penelitian menyatakan bahwa variabel kesulitan keuangan tidak berpengaruh terhadap auditor switching. Hal ini dimungkinkan pada saat perusahaan mengalami kesulitan keuangan, dapat diartikan juga bahwa perusahaan tersebut tidak dapat memenuhi kewajiban finansialnya. Oleh sebab itu, untuk menghindari persepsi negative dari para investor perusahaan yang mengalami kesulitan keuangan cenderung tidak melakukan auditor switching (Wijayani \& Januarti, 2011).

Hasil penelitian ini mendukung penelitian sebelumnya Aroh et al. (2017), Susanto (2018), Sari \& Astika (2018), Winata \& Anisykurlillah (2018), Pratiwi \& RM (2019), Safriliana \& Muawanah (2019), Rahmi et al. (2019), dan Andini et al. (2020) namun bertentangan dengan penelitian yang dilakukan oleh Agiastuti \& Suputra (2016) dan (Kusuma \& Farida, 2019).

\section{Pengaruh Ukuran KAP terhadap Auditor Switching}

Hasil penelitian menyatakan bahwa variabel ukuran KAP tidak berpengaruh terhadap auditor switching. Hal ini dimungkinkan ukuran KAP tidak termasuk faktor yang berkontribusi besar dalam memengaruhi auditor switching. Bergantinya KAP dari Big-four ke non Big-four ditakutkan akan menimbulkan adanya pandangan negatif dari investor terhadap mutu pelaporan keuangan perusahaan. Sebaliknya, bergantinya KAP dari non Big-four ke Big-four ditakutkan akan menimbulkan tidak adanya kesempatan untuk memperoleh opini wajar tanpa pengecualian sebab alasan mutu audit yang lebih baik.

Hasil penelitian mendukung penelitian sebelumnya oleh Aroh et al. (2017) namun bertentangan dengan penelitian yang dilakukan oleh Abidin et al. (2016), Winata \& Anisykurlillah (2018), Manto \& Manda (2018), dan (Safriliana \& Muawanah, 2019). 


\section{Pengaruh Pergantian Manajemen terhadap Auditor Switching}

Hasil penelitian menyatakan bahwa variabel pergantian manajemen tidak berpengaruh terhadap auditor switching. Hal ini dimungkinkan terjadinya pergantian manajemen, lebih erat kaitannya dengan evaluasi kinerja manajemen secara menyeluruh serta rata-rata perusahaan tidak banyak melakukan pergantian manajemen. Di mana fenomena ini ada hubungannya dengan kondisi perusahaan publik di Indonesia yang sebagian besar dikuasai dan dioperasikan bersama dengan orang-orang dalam satu keluarga. Dengan kata lain, apabila ada pergantian manajemen maka tidak diharuskan pula adanya pergantian auditor (auditor switching) (Damayanti \& Sudarma, 2012).

Hasil penelitian ini mendukung penelitian sebelumnya oleh Susanto (2018) dan Andreas \& Savitri (2019) namun bertentangan dengan penelitian yang dilakukan oleh Abidin et al. (2016), Agiastuti \& Suputra (2016), Manto \& Manda (2018), dan (Winata \& Anisykurlillah, 2018).

\section{Pengaruh Opini Audit terhadap Auditor Switching}

Hasil penelitian menyatakan bahwa variabel opini audit tidak berpengaruh terhadap auditor switching. Hal ini dimungkinkan karena sebagian besar perusahaan sampel penelitian memperoleh opini wajar tanpa pengecualian. Perusahaan dengan opini selain wajar tanpa pengecualian lebih mengarah untuk melakukan pergantian auditornya daripada perusahaan dengan opini wajar tanpa pengecualian (Widnyani \& RM, 2018).

Hasil penelitian ini mendukung penelitian sebelumnya oleh Winata \& Anisykurlillah (2018), Andreas \& Savitri (2019), Kusuma \& Farida (2019), Safriliana \& Muawanah (2019), dan (Andini et al., 2020) namun bertentangan dengan hasil penelitian yang dilakukan oleh Abidin et al. (2016), Budisantoso et al. (2017), dan (Susanto, 2018).

\section{Pengaruh Ukuran Perusahaan terhadap Auditor Switching}

Hasil penelitian menyatakan bahwa variabel ukuran perusahaan berpengaruh terhadap auditor switching. Hal ini dimungkinkan karena perusahaan yang besar memiliki kemampuan lebih untuk mengadakan perubahan terhadap auditornya. Dimana semakin besar total asset perusahaan, maka membuktikan semakin besar pula ukuran perusahaan tersebut sehingga perusahaan mempunyai pendanaan yang cukup dalam merekrut auditor eksternal yang dirasa lebih mendapatkan kepercayaan dari pihak investor (Wijayani \& Januarti, 2011).

Hasil penelitian ini mendukung penelitian sebelumnya oleh Abidin et al. (2016), Winata \& Anisykurlillah (2018), Safriliana \& Muawanah (2019), dan Pratiwi \& RM (2019) namun bertentangan dengan hasil oleh (Rahmi et al., 2019).

\section{KESIMPULAN}

Berdasarkan analisis menggunakan regresi logistik (logistic regression), maka disimpulkan :

1. Hasil uji analisis regresi logistik membuktikan bahwa kesulitan keuangan tidak memengaruhi terhadap auditor switching pada sub sector property dan real estate periode 2017-2019. Hal ini dimungkinkan pada saat perusahaan mengalami kesulitan keuangan, dapat diartikan juga bahwa perusahaan tersebut tidak dapat memenuhi kewajiban finansialnya. Oleh sebab itu, untuk menghindari persepsi negative dari para investor perusahaan yang mengalami kesulitan keuangan cenderung tidak melakukan auditor switching (Wijayani \& Januarti, 2011).

2. Hasil uji analisis regresi logistik membuktikan bahwa ukuran KAP tidak memengaruhi auditor switching pada sub sector property dan real estate periode 2017-2019. Hal ini dimungkinkan ukuran KAP tidak termasuk faktor yang berkontribusi besar dalam memengaruhi auditor switching. Bergantinya KAP dari Big-four ke non Big-four ditakutkan akan menimbulkan adanya pandangan negatif dari investor terhadap mutu pelaporan keuangan perusahaan. Sebaliknya, bergantinya KAP dari non Big-four ke Big-four ditakutkan akan menimbulkan tidak adanya kesempatan untuk memeroleh opini wajar tanpa pengecualian sebab alasan mutu audit yang lebih baik.

3. Hasil uji analisis regresi logistik membuktikan bahwa pergantian manajemen tidak memengaruhi auditor switching pada sub sector property dan real estate periode 2017-2019. Hal ini dimungkinkan terjadinya pergantian manajemen, lebih erat kaitannya dengan evaluasi kinerja manajemen secara menyeluruh serta rata-rata perusahaan tidak banyak melakukan pergantian manajemen. Di mana fenomena ini ada hubungannya dengan kondisi perusahaan publik di Indonesia yang sebagian besar dikuasai dan dioperasikan bersama dengan orang-orang dalam 
satu keluarga. Dengan kata lain, apabila ada pergantian manajemen maka tidak diharuskan pula adanya pergantian auditor (auditor switching) (Damayanti \& Sudarma, 2012).

4. Hasil uji analisis regresi logistik membuktikan bahwa opini audit tidak memengaruhi auditor switching pada sub sector property dan real estate periode 2017-2019. Hal ini dimungkinkan karena sebagian besar perusahaan sampel penelitian memperoleh opini wajar tanpa pengecualian. Perusahaan dengan opini selain wajar tanpa pengecualian lebih mengarah untuk melakukan pergantian auditornya daripada perusahaan dengan opini wajar tanpa pengecualian (Widnyani \& $\mathrm{RM}, 2018$ ).

5. Hasil uji analisis regresi logistik membuktikan bahwa ukuran perusahaan memengaruhi auditor switching pada sub sector property dan real estate periode 2017-2019. Hal ini dimungkinkan karena perusahaan yang besar memiliki kemampuan lebih untuk mengadakan perubahan terhadap auditornya. Dimana semakin besar total asset perusahaan, maka membuktikan semakin besar pula ukuran perusahaan tersebut sehingga perusahaan mempunyai pendanaan yang cukup dalam merekrut auditor eksternal yang dirasa lebih mendapatkan kepercayaan dari pihak investor (Wijayani \& Januarti, 2011).

\section{KETERBATASAN}

Penelitian ini tedapat keterbatasan-keterbatasan sebagai berikut :

1. Variabel dalam penelitian ini terbatas pada variabel auditor switching, kesulitan keuangan, ukuran KAP, pergantian manajemen, opini audit, dan ukuran perusahaan.

2. Sampel penelitian hanya berfokus pada sub sector property dan real estate dengan periode 3 tahun (2017-2019).

\section{SARAN}

Berdasarkan keterbatasan, peneliti memberikan saran bagi peneliti selanjutnya sebagai berikut :

1. Saran Teoritis

a) Menambahkan atau mengganti variabel yang dimungkinkan berpengaruh terhadap auditor switching seperti audit fee, audit tenure, dan kualitas audit.

b) Penelitian selanjutnya disarankan untuk menggunakan perusahaan selain sub sector property dan real estate dan memperpanjang periode penelitian.

2. Saran Praktis

a) Bagi Kantor Akuntan Publik

Hasil penelitian ini diharapkan dapat membantu kantor akuntan publik dengan memberikan acuan untuk mengetahui faktor-faktor yang dapat memengaruhi auditor switching.

b) Bagi Perusahaan

Hasil penelitian ini diharapkan dapat digunakan dalam pengambilan keputusan, agar perusahaan mempertimbangkan keputusannya dalam melakukan auditor switching.

c) Bagi Profesi Auditor

Dapat digunakan sebagai sumber informasi untuk profesi auditor mengenai auditor switching oleh perusahaan.

d) Bagi Peneliti Selanjutnya

Untuk memacu dan mendorong peneliti selanjutnya meneliti lebih banyak terkait dengan auditor switching serta dapat menjadi salah satu sumber referensi untuk penelitian selanjutnya

\section{REFERENSI}

Abidin, S., Ishaya, I. V., \& M-Nor, M. N. (2016). The association between corporate governance and auditor switching decision. International Journal of Economics and Financial Issues, 6(7Special Issue), 77-80.

Agiastuti, I. A. P., \& Suputra, I. D. G. D. (2016). Faktor-Faktor Yang Berpengaruh Pada Voluntary Auditor Switching. E-Jurnal Akuntansi, 17(1), 56-83.

Andini, S., Pulomas, J., \& Kav, S. (2020). Analisis Faktor-Faktor Yang Mempengaruhi Auditor Switching Pada Perusahaan Manufaktur under a Creative Commons Attribution (CC-BY-NCSA) 4.0 license. Jurnal Riset Manajemen Dan Bisnis (JRMB) Fakultas Ekonomi UNIAT, 5(2), 121-132. http://jrmb.ejournal-feuniat.net/index.php/JRMB/article/view/415 
Andreas, \& Savitri, E. (2019). Auditor switching behavior in LQ45 companies in Indonesia. International Journal of Scientific and Technology Research, 8(5), 53-57.

Aprilia, E. (2013). Analisis Faktor-Faktor Yang Mempengaruhi Auditor Switching. Jurnal Akuntansi, Vol. 1 No.

Aroh, J. C., Odum, A. N., \& Odum, C. G. (2017). Determinants of auditor switch : evidence from quoted companies in Nigeria. Intenasional Journal of Management Research and Business Strategy, 6(4), 27-40.

Arsih, \& Anisykurlillah. (2015). Pengaruh Opini Going Concern, Ukuran KAP dan Profitabilitas Terhadap Auditor Switching. Accounting Analysis Journal, 4.

Aurora, F. (2013). Analisis Faktor - Faktor Yang Mempengaruhi Auditor Switching. Skripsi.

Budisantoso, T., Rahmawati, R., Bandi, B., \& Probohudono, A. N. (2017). Determinant of Downward Auditor Switching. Jurnal Akuntansi Multiparadigma, 8(3), 444-457. https://doi.org/10.18202/jamal.2017.12.7065

Damayanti, S., \& Sudarma, M. (2012). Faktor-Faktor Yang Mempengaruhi Perusahaan Berpindah Kantor Akuntan Publik. Simposium Nasional Akuntansi XI Pontianak, 66, 37-39.

Efendy, \& Rahayu. (2015). Analisis Pengaruh Opini Audit, Ukuran Kantor Akuntan Publik, Ukuran Perusahaan Klien, dan Kepemilikan Manajerial Terhadap Auditor Switching. Jurnal Akuntansi Dan Keuangan, 4.

Faradina, Z., \& Efrizal, S. (2019). Pengaruh Financial Distress, Pertumbuhan Perusahaan Klien, Ukuran KAP, dan Audit Delay terhadap Auditor Switching. Jurnal Eksplorasi Akuntansi, 1, 1556-1568.

Hermansyah, \& Fadil, A. (2019). KemenBUMN sudah minta komisaris lakukan audit dengan KAP berbeda. https://www.alinea.id/bisnis/kemenbumn-sudah-minta-komisaris-lakukan-auditdengan-kap-be-b1XhU9lgP

Hery. (2016). Analisis Laporan Keuangan. Jakarta : Grasindo

Hilmi, \& Ali. (2008). Analisis Faktor-faktor yang Mempengaruhi Ketepatan Waktu Penyampaian Laporan Keuangan. Jurnal Ekonomi Dan Bisnis.

Ichsan, R. (2013). Teori Keagenan (Agency Theory).

Juliantari, N. W. A., \& Rasmini, N. K. (2013). Auditor Switching Dan Faktor-Faktor Yang Mempengaruhinya. E-Jurnal Akuntansi, 3(3), 231-246.

Kasmir. (2016). Analisis Laporan Keuangan. Jakarta : Raja Grafindo Persada

Kusuma, H., \& Farida, D. (2019). Likelihood of Auditor Switching: Evidence for Indonesia. International Journal of Research in Business and Social Science (2147-4478), 8(2), 29-40. https://doi.org/10.20525/ijrbs.v8i2.192

Lindrianasari. (2010). Pergantian CEO Dunia. Yogyakarta : Kanisius

Manto, J. I., \& Manda, D. L. (2018). Pengaruh Financial Distress, Pergantian Manajemen Dan Ukuran Kap Terhadap Auditor Switching. Media Riset Akuntansi, Auditing \& Informasi, 18(2), 205. https://doi.org/10.25105/mraai.v18i2.3212

Mulyadi. (2014). Sistem Akuntansi (Keempat). Jakarta : Salemba Empat.

Pradhana, M. A. B. (2015). Pengaruh Audit Fee, Going Concern, Financial Distress, Ukuran Perusahaan, Pergantian Manajemen Pada Pergantian Auditor. Jurnal Akuntansi Universitas Udayana, 713-729.

Pratini, I. G. A., \& Astika, I. B. (2013). Fenomena Pergantian Auditor di Bursa Efek Indonesia. EJurnal Akuntansi, 5, 470-486. 
Pratiwi, I. D. A. A., \& RM, K. M. (2019). Pengaruh Financial Distress, Ukuran Perusahaan, dan Audit Delay Terhadap Pergantian Auditor. E-Jurnal Akuntansi, 26, 1048. https://doi.org/10.24843/eja.2019.v26.i02.p08

Rahmi, N. U., Stefano, J., Silfenni, \& Saragih, B. V. A. (2019). Pengaruh Opini Audit, Financial Distress, dan Ukuran Perusahaan terhadap Auditor Switching pada Perusahaan Konsumsi di Bursa Efek Indonesia. Jurnal Ilmiah MEA (Manajemen, Ekonomi, \& Akuntansi), 3(3), 76-85. https://doi.org/10.31955/mea.vol4.iss1.pp26

Ramadona, A. (2016). Pengaruh Struktur Kepemilikan Manajerial, Struktur Kepemilikan Institusional, Ukuran Perusahaan Dan Leverage Terhadap Konservatisme Akuntansi. JOM Fekon, 3, 23572370 .

Riyanto, B. (2013). Dasar-Dasar Pembelanjaan Perusahaan (Keempat). BPFE-Yogyakarta.

Ross, Westerfield, S. R. W., \& Jaffe, J. (2013). Fundamental of Corporate Finance (9th ed.). Mc GrawHill.

Safriliana, R., \& Muawanah, S. (2019). Faktor yang Memengaruhi Auditor Switching di Indonesia. Universitas Merdeka Malang. Jurnal Akuntansi Aktual, 5(3), 234-240. homepage:http://journal2.um.ac.id/index.php/jaa

Sari, G. A. A. I. P., \& Astika, I. B. P. (2018). Pengaruh Opini Going Concern, Financial Distress dan Kepemilikan Institusional pada Auditor Switching. E-Jurnal Akuntansi, 23, 898. https://doi.org/10.24843/eja.2018.v23.i02.p04

Sinarwati, N. K. (2010). Mengapa Perusahaan Manufaktur Yang Terdaftar Di Bei Melakukan Pergantian Kantor Akuntan Publik? Simposium Nasional Akuntansi XIII Purwokerto 2010, 69 73. https://www.bertelsmannstiftung.de/fileadmin/files/BSt/Publikationen/GrauePublikationen/MT_Globalization_Report_2 018.pdf\%0Ahttp://eprints.Ise.ac.uk/43447/1/India_globalisation, society and inequalities(1sero).pdf\%0Ahttps://www.quora.com/What-is-the

Sugianto, D. (2017). Saham Inovisi Resmi Dihapus dari Lantai Bursa. In detikcom.

Sugiyono. (2013). Metode Penelitian Pendidikan Pendekatan Kuantitatif, Kualitatif, dan R\&D. Bandung : Alfabeta

Sundjaja, R., \& Barlian, I. (2001). Manajemen Keuangan Satu (Keempat). Jakarta : PT Prenhallindo

Susanto, Y. K. (2018). Auditor Switching: Management Turnover, Qualified Opinion, Audit Delay, Financial Distress. International Journal of Business, Economics and Law, 15(5), 125-132.

Widiastari, P. A., \& Yasa, G. W. (2018). Pengaruh Profitabilitas, Free Cash Flow, dan Ukuran Perusahaan Pada Nilai Perusahaan. E-Jurnal Akuntansi, 23, 957. https://doi.org/10.24843/eja.2018.v23.i02.p06

Widnyani, N. L. E. D., \& RM, K. M. (2018). Pengaruh Opini Audit, Audit Fee, Reputasi KAP dan Ukuran Perusahaan Klien Terhadap Auditor Switching. E-Jurnal Akuntansi, 23(2), 1119-1145. https://doi.org/10.24843/EJA.2018.v23.i02.p12

Wijayani, E. D., \& Januarti, I. (2011). Analisis Faktor-Faktor yang Mempengaruhi Perusahaan di Indonesia Melakukan Auditor Switching. Simposium Nasional Akuntansi XIV Aceh 2011.

Winata, A. S., \& Anisykurlillah, I. (2018). Analysis of Factors Affecting Manufacturing Companies in Indonesia Performing a Switching Auditor. Jurnal Dinamika Akuntansi, 9(1), 82-91. https://doi.org/10.15294/jda.v9i1.11998 